\title{
Aicardi syndrome: a case report. Beyond ophthalmology
}

\section{Síndrome de Aicardi: reporte de caso. Más allá de la oftalmología}

\author{
Hae Jin Kim", Rodrigo I. Lozano-Garza², Ulises de Dios-Cuadras ${ }^{1}$, Jesús Guerrero-Becerri2, \\ Andrés Urióstegui-Rojas ${ }^{4}$, Oscar F. Chacón-Camacho ${ }^{5}$, Federico Graue-Wiechers ${ }^{1}$, \\ María E. Hofmann-Blancash ${ }^{2}$, and Juan C. Zenteno-Ruiz ${ }^{5}$ \\ ${ }^{1}$ Department of Retina and Vitreous; ${ }^{2}$ Department of Glaucoma; ${ }^{3}$ Department of Cornea; ${ }^{4}$ Department of Comprehensive Ophthalmology; ${ }^{5}$ Department \\ of Genetics. Instituto de Oftalmología Fundación Conde de Valenciana, Mexico City, Mexico
}

\begin{abstract}
Purpose: Aicardi syndrome was originally described in 1965, as a triad of abnormalities that includes partial or total agenesis of the corpus callosum, chorioretinal lacunae, and infantile spasms. Case report: A 1-month-old female was evaluated in the Genetics department with a history of epilepsy, total agenesis of the corpus callosum, and vertebral dysgenesis with scoliosis identified during a previous neurological evaluation. An ophthalmological examination revealed microphthalmia of the right eye and microcornea in the left eye; the rest of the anterior segment showed no alterations. Fundoscopy revealed chorioretinal lesions compatible with chorioretinal lacunae that integrated the diagnosis of Aicardi syndrome. Conclusions: We emphasize the importance of a careful ophthalmologic examination in all patients to identify ophthalmological and systemic abnormalities at an early age and the development and implementation of an individualized therapy plan.
\end{abstract}

Key words: Agenesis of the corpus callosum. Chorioretinal lacunae. Aicardi syndrome.

\section{Resumen}

Objetivo: El síndrome de Aicardi fue descrito en 1965 como una tríada de anormalidades que incluye agenesia parcial o total del cuerpo calloso, lagunas coriorretinianas y espasmos infantiles. Se presenta el caso de una paciente con diagnóstico de síndrome de Aicardi que debutó con manifestaciones neurológicas, por lo que se decidió su abordaje multidisciplinario. Caso clínico: Paciente de sexo femenino, de 1 mes de edad, que llega al departamento de genética con antecedentes de epilepsia (espasmos infantiles), agenesia total de cuerpo calloso y disgenesia vertebral con escoliosis encontradas durante la evaluación neurológica previa. El examen oftalmológico reveló microftalmia en el ojo derecho, microcórnea en el ojo izquierdo presentó y resto del segmento anterior sin alteraciones. En la fundoscopia se observaron lesiones coriorretinianas compatibles con lagunas coriorretinianas, así como coloboma de nervio óptico, por lo que se diagnostica síndrome de Aicardi. Conclusiones: Enfatizamos la importancia del examen oftalmológico completo en todos los pacientes para detectar de manera oportuna cualquier anormalidad, además de realizar siempre un abordaje sistémico que permita un diagnóstico sindromático, e individualizar el plan terapéutico.

Palabras clave: Agenesia del cuerpo calloso. Lagunas coriorretinianas. Síndrome de Aicardi.

Correspondence:

*Hae Jin Kim Chimalpopoca, 14

Col. Obrera, Alcaldía Cuauhtémoc Date of reception: 28-01-2020

C.P. 06800, Mexico City, Mexico

E-mail: hjkim.med@gmail.com
Available online: 19-03-2021

Rev Mex Oftalmol (Eng). 2021;95(4):160-163

www.rmo.com.mx

2604-1731/@ 2020 Sociedad Mexicana de Oftalmología. Published by Permanyer. This is an open access article under the CC BY-NC-ND license (http://creativecommons.org/licenses/by-nc-nd/4.0/). 


\section{Introduction}

Aicardi syndrome (AS) was described in 1965 by Jean Aicardi and is characterized by a triad of abnormalities that includes total or partial agenesis of the corpus callosum, chorioretinal lacunae and infantile spasms $^{1,2}$.

AS is estimated to have an incidence of $1: 100,000$ in the United States of America and 1:93,000 in the Netherlands. So far, only 4,000 cases have been described in the global medical literature ${ }^{3,4}$.

The diagnosis of AS is still based on the presence of the clinical triad; however, new imaging studies allow diagnosis of atypical or incomplete cases. Infantile spasms are the most common type of epilepsy in AS and in most cases, they appear at an early age (3-4 months) $)^{1,3}$.

A distinctive feature of AS, in addition to brain findings, are ocular manifestations. Chorioretinal lacunae are pathognomonic of AS. Other ocular alterations that can be observed are microphthalmia, persistent pupillary membrane, chorioretinal coloboma, choroidal neovascularization, abnormalities of the optic nerve including hypoplasia, coloboma, morning glory disc anomaly, serous retinal detachment, and glial tissue extending from the $\operatorname{disc}^{5-9}$.

Non-neurological alterations include costovertebral defects, such as the absence of bifurcation of the ribs, and scoliosis, which occurs in half of the cases ${ }^{1,3}$.

The relevance of this case report lies in the fact that the first manifestations of the patient were neurological, for which it was decided to evaluate her by the genetics and ophthalmology services.

The objective of this article is to make the Mexican ophthalmology community aware of the importance of an interdisciplinary and multidisciplinary approach for rare genetic syndromes that show key ocular signs and allow an accurate diagnosis.

\section{Clinical case}

This is the case of a 1-month-old female presenting to the genetics department with a history of epilepsy, total agenesis of the corpus callosum, and spinal dysgenesis with scoliosis, identified during a previous neurological evaluation (Fig. 1). She was the product of the third pregnancy of non-consanguineous parents and was born by cesarean section with a full-term pregnancy without complications. She did not require advanced cardiopulmonary resuscitation maneuvers; her birth weight was 2,900 g and her height was $49 \mathrm{~cm}$; scores

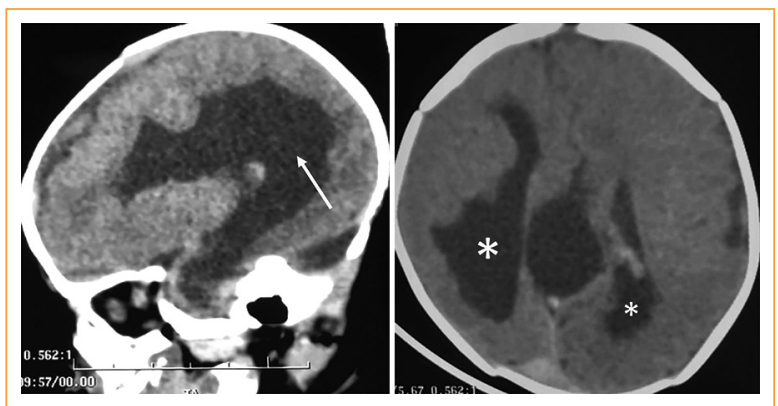

Figure 1. Tomography images showing total agenesis of the corpus callosum (arrow) and gray matter heterotopia (asterisks).

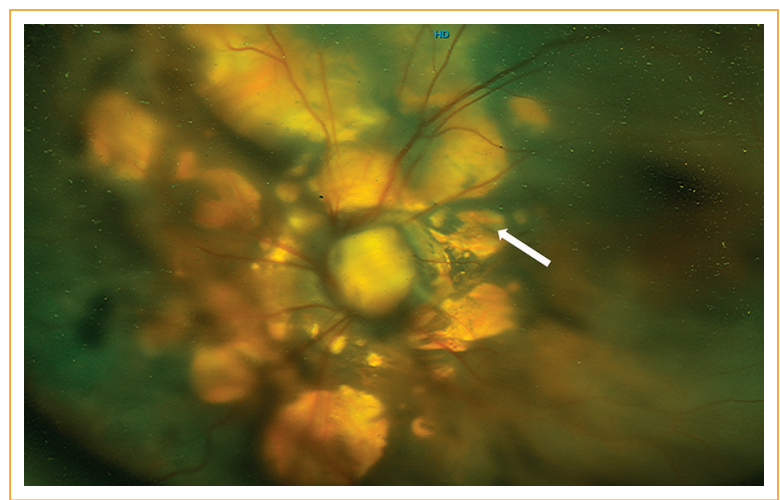

Figure 2. Fundoscopy of the left eye showing an optic nerve coloboma and multiple flat chorioretinal lesions with peripapillary distribution and variable amount of pigment on their edges, suggestive of chorioretinal lacunae (arrow).

on the Apgar and Silverman-Anderson scales are unknown.

On physical examination at one month of age, the patient showed generalized hypotonia without organomegaly. Ocular examination showed shortening of the cul-de-sac in both eyes, and microphthalmia in the right eye; the rest of the structures could not be evaluated. Microcornea was observed in the left eye and the rest of the anterior segment was normal. Fundoscopy of the left eye showed the optic nerve with an asymmetric excavation and a small nasal residual neuro-retinal rim, minimal peripapillary pigment and abnormal vasculature with central emergence corresponding to a coloboma. In addition, there were multiple chorioretinal lesions measuring approximately one disc area, yellowish, ovoid, with a variable amount of pigment on the edges and distributed in the peripapillary area confined to the posterior pole, suggestive of chorioretinal lacunae (Fig. 2). An ocular ultrasound showed an axial length of 
Table 1. Modified diagnostic criteria for Aicardi syndrome

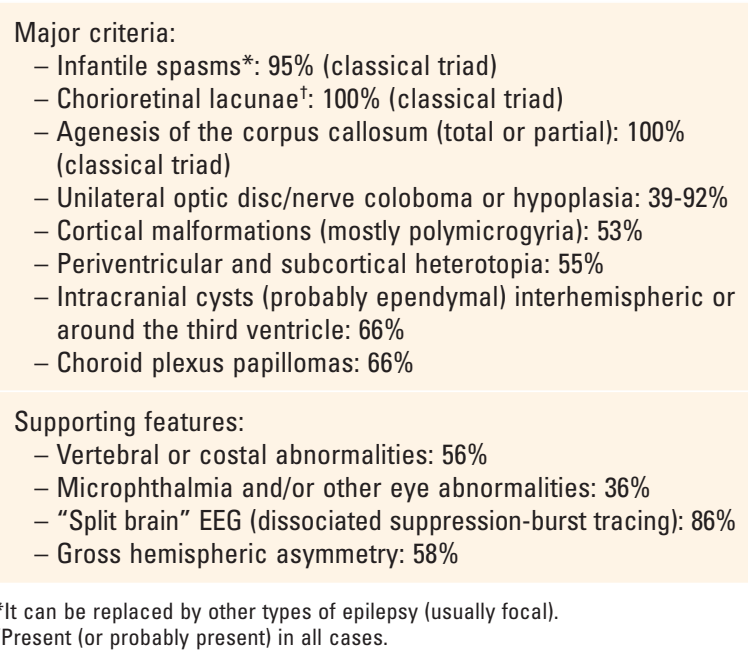

the right eye of $14.94 \mathrm{~mm}$, confirming the diagnosis of microphthalmia. As part of the evaluation, the genetics department requested a karyotype, which reported 46, $X X$. The neurology department indicated treatment with valproic acid $(250 \mathrm{mg} / 5 \mathrm{ml})$ every 8 hours by enteral administration, clonazepam $(0.48 \mathrm{mg})$ every 24 hours by oral administration, vigabatrin (500 mg) every 12 hours by oral administration and levetiracetam (100 mg/2.2 ml) every 12 hours intravenously. We proceed to evaluate from different departments, such as glaucoma, retina, oculoplastic and low vision to decide the best management. The approach, in this case, were treatment for amblyopia and an ocular prosthesis for the right eye, as well as explaining to her parents about poor functional visual prognosis in both eyes due to the underlying disease.

Unfortunately, the patient died of complications from community-acquired pneumonia with respiratory distress syndrome, septic shock, and finally, cardiorespiratory arrest at 1 year and 7 months of age.

\section{Discussion}

To establish the diagnosis of AS, the presence of the classic triad or the presence of two of the classic triad components plus at least two other major or supporting features $^{1,3}$ (Table 1) is required. Our patient had the classic triad and two other supporting features for the diagnosis of AS.

The ophthalmological examination is the key for the diagnosis and it must be performed by an ophthalmologist who has been trained in pediatric ophthalmology or by a geneticist who is specialized in ocular diseases ${ }^{7}$. In $100 \%$ of cases reported in the literature, they consider chorioretinal lacunae as pathognomonic feature of $\mathrm{AS}^{5-9}$. They are yellow or yellowish-white, round lesions of variable size with peripapillary location in the posterior pole. Histopathological examination shows a hypopigmented retinal pigment epithelium with retinal disorganization. Optic nerve abnormalities are common and colobomas are the most common presentation, in up to $39 \%$ of cases. However, other alterations have also been described such as morning glory disc anomaly occupying the second place in $21-86 \%$ of cases. The presence of microphthalmia, more common on the right side, and other alterations such as abnormalities of the retinal vessels have also been described ${ }^{5-9}$.

Currently there is still not a clear genetic component, but it is suspected that it may be related to X-linked genetic mutation, since the reported cases are exclusively in female patients, such as our case. Few cases reported in males were identified like 47 , XXY karyotype and only one case was a 46, XY karyotype. Therefore, some authors suggest that the process of $X$ chromosome inactivation may explain the variability and asymmetry observed in this disease, which supports that they have a greater prevalence of skewed $X$ chromosome inactivation in peripheral lymphocytes in AS, particularly, those with neurological involvement ${ }^{10}$.

A pediatric neurologist experienced in managing infantile spasms is essential for the long-term treatment of patients with AS, who frequently require several antiepileptic drugs for adequate seizure control, as in this case. In the case series, the main characteristics are total or partial agenesis of the corpus callosum (100\%) and infantile spasms (95\%), signs that belong to the classic triad. Other features that may be observed include grey matter heterotopia (55\%), polymicrogyria $(53 \%)$, intracranial cysts $(66 \%)$ and choroid plexus papillomas $(66 \%)^{1,4,6}$.

Additional interventions include: physiotherapy, occupational therapy, speech therapy, and visual therapy. They should be settled as soon as possible to ensure the best development and functionality of the different sense organs. Costovertebral defects can lead to scoliosis, as in our case. Adequate musculoskeletal support and treatment for the prevention of related complications are indicated ${ }^{3}$.

The survival rate is $76 \%$ up to 6 years of age and $40 \%$ up to 14 years of age. Most patients deteriorate in the first 5-6 years of life, and it is difficult to determine the complications of the malformations and 
the consequences of uncontrolled epilepsy. Most patients remain with short stature as a consequence of scoliosis ${ }^{1}$.

The limitation of this case report is the poor ophthalmological follow-up of the patient, due to numerous admissions to the pediatric emergency room secondary to repetitive lower respiratory tract infections. This led to difficulties in the ambulatory follow-up of the patient. Finally, we were not able to evaluate her evolution secondary to her death at 1 year and 7 months of age.

In conclusion, we must emphasize the importance of a complete ophthalmological evaluation; necessary to help to establish an individualized therapeutic plan. Regarding visual therapy, we recommend the early implantation of prostheses in cases of shortening of the cul-de-sac, to achieve an adequate aesthetic and anatomical appearance. If the visual pathways are unaltered, visual stimulation (done by ophthalmologists specialized in low vision) and psychological counseling for the patient and family members must be performed.

\section{Funding}

The authors did not receive any funding for this work.

\section{Conflicts of interest}

The authors declare no conflicts of interest.

\section{Ethical disclosures}

Protection of human and animal subjects. The authors declare that no experiments were performed on humans or animals for this study.

Confidentiality of data. The authors declare that they have followed the protocols of their work center on the publication of patient data.

Right to privacy and informed consent. The authors have obtained the written informed consent of the patients or subjects mentioned in the article. The corresponding author is in possession of this document.

\section{References}

1. Aicardi J. Aicardi syndrome. Brain Dev. 2005;27:164-71.

2. Fernández-Ramos JA, López-Laso E, Simón-De Las Heras R, Camino-León R, Guerra-García P, Camacho-Salas A, et al. Aicardi syndrome: retrospective study of a series of seven case reports. Rev Neurol. 2013;57:481-8.

3. Sutton VR, Hopkins BJ, Eble TN, Gambhir N, Lewis RA, Van den Veyver IB. Facial and physical features of Aicardi syndrome: infants to teenagers. Am J Med Genet A. 2005;138A:254-8.

4. Kroner BL, Preiss LR, Ardini MA, Gaillard WD. New incidence, prevalence, and survival of Aicardi syndrome from 408 cases. J Child Neurol. 2008;23:531-5.

5. Fruhman G, Eble TN, Gambhir N, Sutton VR, Van den Veyver IB, Lewis RA. Ophthalmologic findings in Aicardi syndrome. J AAPOS. 2012;16:238-41.

6. Cabrera MT, Winn BJ, Porco T, Strominger Z, Barkovich AJ, Hoyt CS, et al. Laterality of brain and ocular lesions in Aicardi syndrome. Pediatr Neurol. 2011;45:149-54

7. Shah PK, Narendran V, Kalpana N. Aicardi syndrome: the importance of an ophthalmologist in its diagnosis. Indian J Ophthalmol. 2009:57:234.

8. Martel JN, Rutar T, Lujan BJ, de Alba Campomanes A. (2011). Chorioretinal architecture in Aicardi syndrome: an optical coherence tomography and fluorescein angiography study. J AAPOS. 2011;15:308-10.

9. Galdós M, Martínez R, Prats JM. Clinical outcome of distinct Aicardi syndrome phenotypes. Arch Soc Esp Oftalmol. 2008;83:29-36.

10. Lund $C$, Striano $P$, Sorte HS, Parisi $P$, lacomino $M$, Sheng $Y$, et al Exome sequencing fails to identify the genetic cause of Aicardi syndrome. Mol Syndromol. 2016;7:234-8. 